\title{
Aplikasi Online Berbasis Android "SI TekO" (Sistem Informasi Teknisi Online) Sebagai Solusi Mempermudah Masyarakat Dalam Mendapatkan Jasa Service
}

\author{
Romi Nur Asfi Akbar¹, Fahmi Bayu Indiarto², Arfani Nanda Aristiantoro ${ }^{3}$, \\ Yudo Bismo Utomo ${ }^{4}$ \\ 1,2,3,4 Teknik Elektro, Fakultas Teknik, Universitas Islam Kadiri Kediri \\ E-mail: *1 nurromy41@ gmail.com, ${ }^{2}$ Fahmibayu68@gmail.com , \\ ${ }^{3}$ arfaniaristiantoro@gmail.com ${ }^{4}$ yudobismo@uniska-kediri.ac.id,
}

\begin{abstract}
Abstrak - Pada era industry 4.0 ini masyarakat Indonesia tenaga manusia sudah digantikan oleh mesin atau computer maka dari itu peneliti membuat suatu aplikasi berbasis SI-TekO. Seperti halnya jika saat barang elektronika,IT, maupun instalasi rusak ingin memperbaiki ataupun memasang alat dirumah akan menjadikan lebih mudah dengan menggunakan jasa online. Jasa sering dipandang sebagai suatu fenomena yang rumit. Kata jasa itu sendiri mempunyai banyak arti, dari mulai pelayanan pribadi sampai pelayanan jasa sebagai suatu produk. Produksi jasa mungkin berkaitan dengan produk fisik atau tidak. Sering sekali yang menjadi problematika adalah saat kita repot dalam bekerja sehingga kita kurang adanya waktu untuk mencari jasa reparasi perangkat elektronik kita, dan pasang instalasi yang kita harapkan. Maka dari itu peneliti membuat sebuah aplikasi berbasis android yang dinamakan SI-TekO. Hasil dari penelitian ini adalah aplikasi berbasis android yang $S I-T e k O$.
\end{abstract}

Kata Kunci - Sistem Informasi, Teknisi Online, Android.

Abstract - In this industry 4.0 era, Indonesian people have been replaced by machines or computers, so researchers have created an SI-TekO-based application. As if when electronic goods, IT, or damaged installations want to repair or install tools at home, it will be easier to use online services. Services are often seen as a complicated phenomenon. The word service itself has many meanings, from personal service to service as a product. Production of services may be related to physical products or not. Very often the problem is when we are bothered at work so we lack the time to look for repair services for our electronic devices, and install the installation that we expect. Therefore the researchers created an android-based application called SI-TekO. The results of this study are Android-based applications that are SI-TekO.

Keywords - Information System, Online Technician, Android.

\section{PENDAHULUAN}

Saat ini kondisi penduduk indonesia dari tahun ketahun selalu mengalami kenaikan, sehingga mempengaruhi jumlah kebutuhan manusia yang tiada batasnya.Seperti halnya jika saat barang elektronika,IT, maupun instalasi rusak ingin memperbaiki ataupun memasang alat dirumah akan menjadikan lebih mudah dengan menggunakan jasa online.

Jasa sering dipandang sebagai suatu fenomena yang rumit. Kata jasa itu sendiri mempunyai banyak arti, dari mulai pelayanan pribadi sampai pelayanan jasa sebagai suatu produk. (Rambat Lupiyoadi:2013). Sebenarnya banyak pakar mengemukakan mengenai apa itu jasa, seperti yang dikemukakan oleh kotler (2004) dalam Rambat Lupianto (2013) mendefinisikan jasa adalah setiap tindakan dan kegiatan yang ditawarkan oleh suatu pihak ke pihak lain, pada dasarnya tidak berwujud dan tidak mengakitbatkan perpindahan kepemilikan apapun. Produksi jasa mungkin berkaitan dengan produk fisik atau tidak.

Banyak sekali contoh dari usaha jasa itu sendiri seperti: jasa transportasi, Salon, Rumah Sakit, Sekolah dan juga jasa reparasi yang pada kesempatan ini kami pilih untuk kami angkat dalam blue print usaha jasa berbasis android yang kami jalankan. Sering sekali yang menjadi problematika 
adalah saat kita repot dalam bekerja sehingga kita kurang adanya waktu untuk mencari jasa reparasi perangkat elektronik kita, dan pasang instalasi yang kita harapkan.

Dengan ini kami mencoba menciptakan aplikasi berbasis android yang memudahkan masyarakat dalam mencari jasa service dan pasang elektronik yang bernama Si TekO. Si TekO ini adalah sebuah aplikasi yang kita usung dalam mengatasi problematika dalam reparasi perangkat elektronik. Sehingga masyarakat akan lebih dekat dengan teknisi yang handal dalam bidang elektronika sehingga menciptakan kenyamanan dalam berkehidupan.

\section{METODE PENELITIAN}

Metode yang akan di pakai dalam penelitian ini menggunakan metode waterfall. Metode waterfall adalah suatu metode dimana penelitian ini dilakukan secara berurutan sesuai dengan siklus pengembangan perangkat lunak [1]. Tahap dari metode waterfall ini adalah sebagai berikut :

1. Requirement.

Layanan sistem,kendala,dan tujuan ditetapkan oleh hasil konsultasi dengan pengguna yang kemudian didefinisikan secara rinci dan berfungsi sebagai spesifikasi sistem.

2. Design.

Tahapan perancangan sistem mengalokasikan kebutuhan-kebutuhan sistem baik perangkat keras maupun perangkat lunak dengan membentuk arsitektur sistem secara keseluruhan. Perancangan perangkat lunak melibatkan identifikasi dan penggambaranabstraksi sistem dasar perangkat lunak dan hubungannya.

3. Implementation

Pada tahap ini, perancangan perangkat lunak direalisasikan sebagai seragkaian program atau unit program. Pengujian melibatkan verifikasi bahwa setiap unit memenuhi spesifikasinya.

4. Testing.

Unit-unit individu program atau program digabung dan diuji sebagai sebuah sistem lengkap untuk memastikan apakah sesuai dengan kebutuhan perangkat lunak atau tidak. Setelah pengujian, perangkat lunaka dapat dikirim ke customer.

5. Maintenance.

Biasanya (walaupun tidak selalu), tahapan ini merupakan tahapan yang paling panjang. Sistem dipasang dan digunakan secara nyata. Maintenance melibatkan pembetulan kesalahan yang tidak ditemukan pada tahapan-tahapan sebelumnya, meningkatkan implentasi dari unit sistem, dan meningkat layanan sistem sebagai kebutuhan baru. berikut ini:

Langkah-langkah dalam penelitian metode waterfall ini, dapat dilihat pada gambar 1.

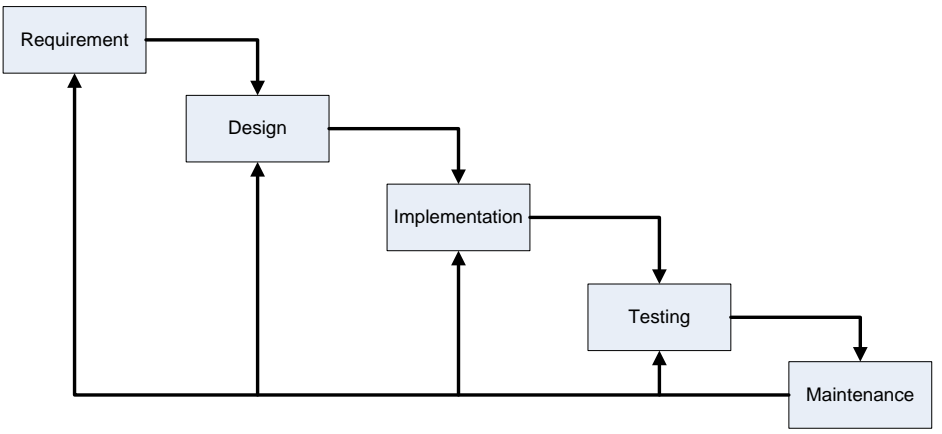

Gambar 1. Alur Penelitian

\section{HASIL DAN PEMBAHASAN}

\subsection{Requirement}

Tahap pertama di dalam analisa kebutuhan di tentukan terlebih dahulu dengan cara konsultasi dengan pengguna, dengan tujuan aplikasi yang di buat nanti bisa memenuhi kebutuhan pengguna. Pada tahap ini didapatkan hasil analisa bahwa yang perlu di buat adalah sistem 
informasi teknisi online pengguna diharuskan menggunakan koneksi untuk menjalankan aplikasi SI-TekO.

\subsection{Design}

Langkah pertama pengguna harus mempunyai akun terlebih dahulu untuk login. Lalu setelah login akan muncul menu tampilan utama yang berisi fitur elektronika dan instalasi. Di dalam fitur elektronika berisi fitur service dan perawatan, sedangkan di dalam fitur instalasi berisi fitur service, perawatan, dan pemasangan. Bila pilihan tidak sesuai bila kembali ke fitur sebelumnya.

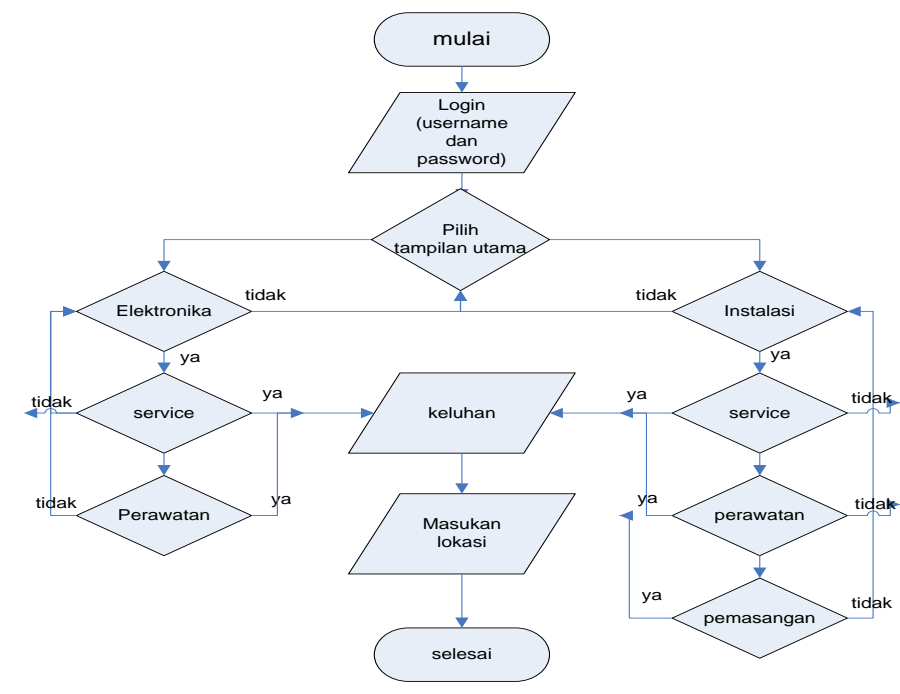

Gambar 2. Rancangan Sistem

\subsection{Implementation}

\subsubsection{Login}

Login adalah fitur untuk masuk kedalam aplikasi bagi pengguna yang sudah memiliki akun, sedangkan yang belum memiliki akun harus daftar terlebih dahulu.

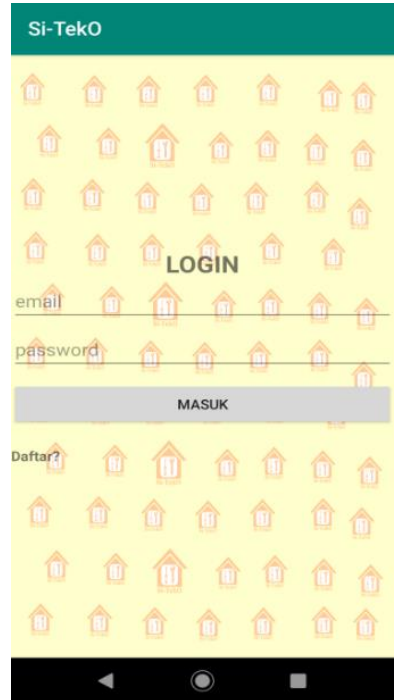

Gambar 3. Fitur Login 


\subsubsection{Daftar}

Fitur daftar berguna untuk membuat akun bagi pengguna yang belum memiliki akun sehingga pengguna harus daftar terlebih dahulu supaya bisa login ke aplikasi Si-TekO

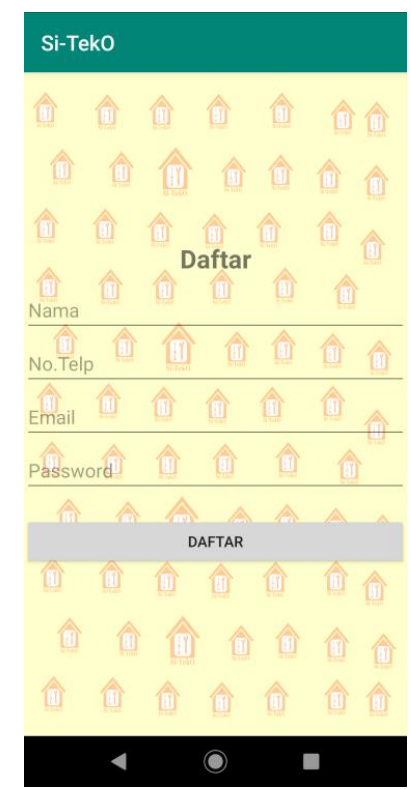

Gambar 4. Fitur Daftar

\subsubsection{Home}

Fitur home merupakan tampilan utama dari aplikasi SI-TekO

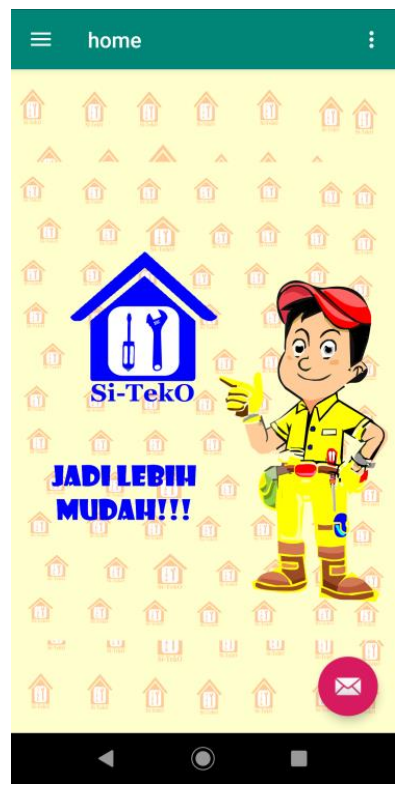

Gambar 5. Fitur Home

\subsubsection{Instalasi}

Menu instalasi merupakan salah satu fitur dalam aplikasi SI-TekO memiliki tiga button yaitu perawatan, service, dan pemasangan. 


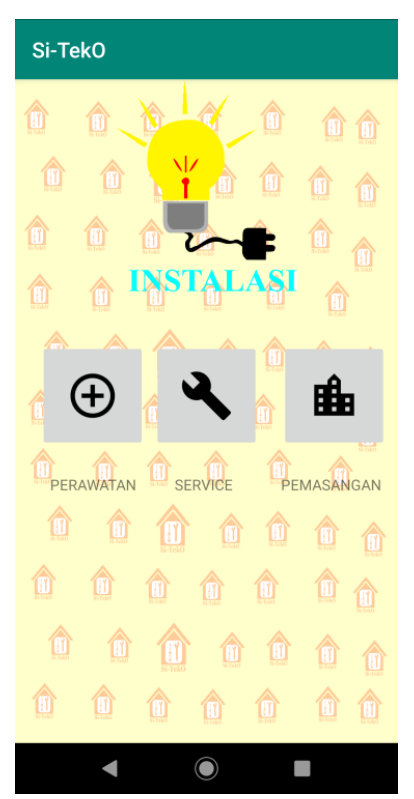

Gambar 6. Menu INSTALASI

\subsubsection{Elektronika}

Menu instalasi merupakan salah satu fitur dalam aplikasi SI-TekO memiliki dua button yaitu perawatan, dan service.

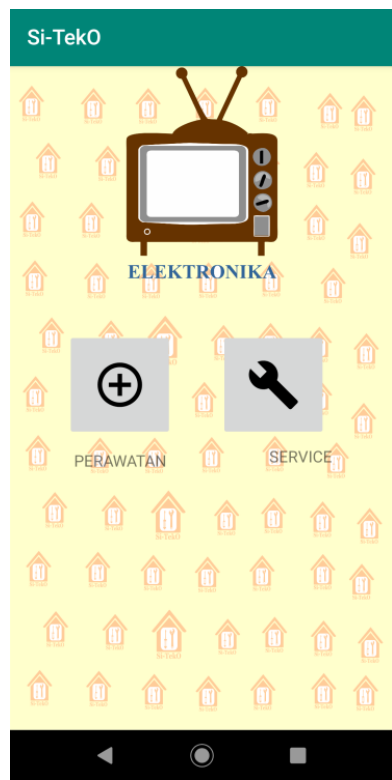

Gambar 7. Menu ELEKTRONIKA

\subsubsection{Profil Pekerja}

Menu profil pekerja merupakan fitur yang digunakan pengguna aplikasi SI-TekO untuk memilih teknisi yang akan di pakai jasanya. 


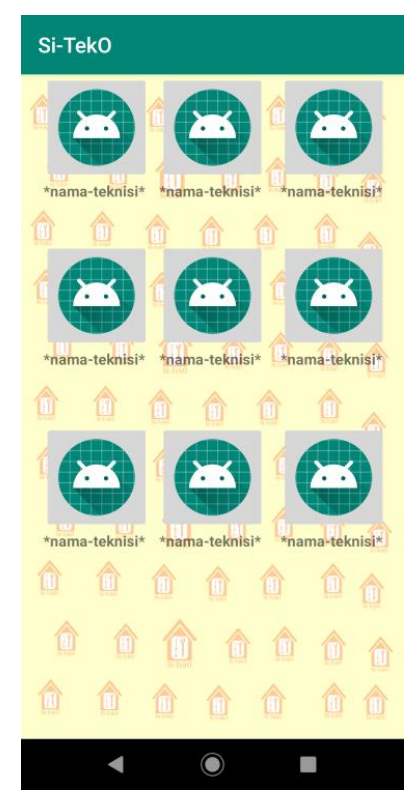

Gambar 8. Menu Profil Pekerja

\subsection{Testing}

1. Pengujian Sistem Login

Tabel 1. Pengujian Sistem Login

\begin{tabular}{|l|l|l|l|l|l|}
\hline No & $\begin{array}{l}\text { Skenario } \\
\text { Pengujian }\end{array}$ & Test Case & $\begin{array}{l}\text { Hasil Yang } \\
\text { Diharapkan }\end{array}$ & $\begin{array}{l}\text { Hasil } \\
\text { Pengujian }\end{array}$ & Status \\
\hline 1 & $\begin{array}{l}\text { Memasukan } \\
\text { Username dan } \\
\text { Password, lalu } \\
\text { langsung klik } \\
\text { "Login" }\end{array}$ & $\begin{array}{l}\text { Username : } \\
\text { admin } \\
\text { Password }: \\
\text { admin }\end{array}$ & $\begin{array}{l}\text { Sistem akan } \\
\text { memberikan hak } \\
\text { akses ke menu sistem } \\
\text { berikutnya. }\end{array}$ & $\begin{array}{l}\text { Sesuai } \\
\text { harapan }\end{array}$ & Valid \\
\hline 2 & $\begin{array}{l}\text { Mengosongkan } \\
\text { Username dan } \\
\text { Password, langsung } \\
\text { klik "Login" }\end{array}$ & $\begin{array}{l}\text { Username : } \\
\text { Password: }:\end{array}$ & $\begin{array}{l}\text { Sistem menolak } \\
\text { akses login dan } \\
\text { menampilkan pesan } \\
\text { "Username Atau } \\
\text { Password Yang } \\
\text { Anda Masukan } \\
\text { Salah, Silahkan coba } \\
\text { lagi" }\end{array}$ & $\begin{array}{l}\text { Belum } \\
\text { sesuai } \\
\text { harapan }\end{array}$ & Unvalid \\
\hline 3 & Klik tombol "Exit" & Klik & Keluar dari sistem & $\begin{array}{l}\text { Sesuai } \\
\text { harapan }\end{array}$ & Valid \\
\hline
\end{tabular}

2. Pengujian Sistem menu SI-TekO

Tabel 2 . Pengujian Sistem Menu SI-TekO

\begin{tabular}{|c|l|c|l|c|l|}
\hline No & Skenario Pengujian & Test Case & \multicolumn{1}{|c|}{$\begin{array}{c}\text { Hasil Yang } \\
\text { Diharapkan }\end{array}$} & $\begin{array}{c}\text { Hasil } \\
\text { Pengujian }\end{array}$ & Status \\
\hline 1 & $\begin{array}{l}\text { Memilih tombol } \\
\text { elektronika dan } \\
\text { instalasi }\end{array}$ & Klik & $\begin{array}{l}\text { Sistem berhasil } \\
\text { membuka tampilan } \\
\text { dalam fitur } \\
\text { elektronika dan } \\
\text { instalasi. }\end{array}$ & $\begin{array}{c}\text { Sesuai } \\
\text { harapan }\end{array}$ & Valid \\
\hline 2 & $\begin{array}{l}\text { Memilih tombol } \\
\text { service, perawatan, dan } \\
\text { pemasangan }\end{array}$ & Klik & $\begin{array}{l}\text { Sistem berhasil } \\
\text { membuka tampilan } \\
\text { dalam fitur service, } \\
\text { perawatan, dan } \\
\text { pemasangan. }\end{array}$ & $\begin{array}{l}\text { Sesuai } \\
\text { harapan }\end{array}$ & Valid \\
\hline
\end{tabular}




\begin{tabular}{|c|l|c|l|c|c|}
\hline 3 & $\begin{array}{l}\text { Memilih tombol nama } \\
\text { teknisi }\end{array}$ & Klik & $\begin{array}{l}\text { Sistem belum } \\
\text { berhasil membuka } \\
\text { tampilan dalam fitur } \\
\text { profil pekerja. }\end{array}$ & $\begin{array}{l}\text { Belum sesuai } \\
\text { harapan }\end{array}$ & Unvalid \\
\hline
\end{tabular}

Setelah dilakukan pengujian rancangan aplikasi, maka tahap selanjutnya yaitu pengujian kelayakan, apakah rancangan aplikasi sistem informasi teknisi online ini layak atau tidak untuk diterapkan di masyarakat. Untuk pengujian kelayakan ini dilakukan proses pengujian dengan mencoba menginstal aplikasi ke smartphone lain. Aspek yangdi perhitungkan dalam pengujian ini, yaitu: tampilan aplikasi, kemudahan pemakaian dan tes error.

\section{Tingkat Respon Aplikasi}

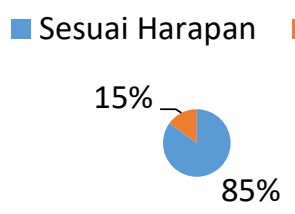

\section{Tampilan aplikasi}
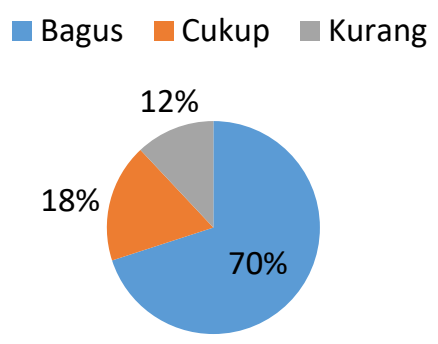

kemudahan pemakaian

user friendly tidak

$25 \%$

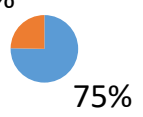

\section{Gambar 9. Grafik Pengujian Kelayakan}

\subsection{Maintenance}

Pada tahap maintenance ini berguna untuk pembaruan dari sistem yang telah dibuat, sehingga perkembangan kedepannya aplikasi SI-TekO ini lebih baik lagi. Fitur yang akan ditambahkan berupa fitur chating yang berguna supaya konsumen bisa berkomunikasi dengan teknisi, serta fitur notifikasi berguna untuk pemberitahuan adanya informasi terbaru.

\section{SIMPULAN}

Aplikasi "Si TekO" (Sistem Informasi Teknisi Online) ini memberikan layanan jasa teknisi online kepada masyarakat untuk mendapat jasa service secara mudah tanpa harus keluar rumah. Dan aplikasi "Si tekO" (Sistem Informasi Teknisi Online) berbasis android.

\section{SARAN}

Untuk pengembangan lebih lanjut serta penyempurnaan dari penelitian ini, maka disarankan agar aplikasi Si TekO ini ditambahkan fitur berupa chating dan notifikasi.

\section{DAFTAR PUSTAKA}

[1] Ginanjar, Wiro Sasmito. 2017. Penerapan Metode Waterfall Pada Desain Sistem Informasi Geografis Industri Kabupaten Tegal. Jurnal Pengembangan IT. Vol 2. No 1. Januari 2017.

[2] Adul Kadir, Pengertian Sistem dan Informasi, Penerbit Andi, Yogyakarta, 2003.

[3] Kristanto Andri, Perancangan Sistem dan Aplikasinya, Penerbit Gava Media, Yogyakarta, 2005.

[4] Android Studio, 2016, Mengenal Android Studio, Diakses Tanggal 21 Maret 2017

[5] Kadir, A., 2008, Belajar Bahasa Database Menggunakan MySQIL, Penerbit Andi Yogyakarta, Yogyakarta 
34 Generation Journal /Vol.5 No.1 / e-ISSN: 2549-2233 / p-ISSN: 2580-4952

[6] Ainindra. 2009. Android Adalah - Pengertian Android - Sistem Operesasi. 15 Januari 2016, $10: 51: 40$

[7] Android. 2013. Android 4.4 comtability definition. 18 Juni 2016, 12:23:59

[8] Google Play. 2016. camScanner - Phone PDF Creator. 04 November 2015, 10:32:01 